\title{
Kalevala-sarja Uuno Klamiego jako dzieło przełomowe fińskiego narodowego modernizmu
}

\author{
Wojciech Stępień \\ Akademia Muzyczna im. Karola Szymanowskiego w Katowicach \\ wojciech.marcin.stepien@gmail.com
}

\begin{abstract}
Abstrakt
„Rosyjscy moderniści, tacy jak Prokofiew i Strawiński, i nowa muzyka hiszpańska wstrząsnęli mną od stóp do głów. [...] Stało się to w tym czasie, gdy poszedłem do Sorbony wypożyczyć kopię Kalewali” (Virtanen 1945: 613-614). Zdanie to zostało wypowiedziane przez fińskiego kompozytora Uuno Klamiego (1900-1961), który podczas studiów muzycznych w Paryżu w latach 1924-1925 zafascynował się muzyką Igora Strawińskiego, Maurycego Ravela, Sergiusza Prokofiewa i Manuela de Falli. Inspirując się osiągnięciami zachodnich modernistów, Klami pragnął przełamać zapoczątkowaną przez Jeana Sibeliusa tendencję do traktowania fińskiego eposu Kalewali jedynie w duchu narodowego romantyzmu. W latach 30. XX wieku pod wpływem partytury Święta wiosny Strawińskiego rozpoczął komponowanie utworu wokalno-instrumentalnego opartego na tematach zaczerpniętych z Kalewali. Jednak w trakcie pracy nad dziełem Klami zmienił pierwotne założenia utworu, dzięki czemu powstała suita orkiestrowa Kalevala-sarja op. 23 [Suita z Kalewali] składająca się z pięciu części: Maan synty [Stworzenie ziemi], Kevään oras [Kiełki wiosny], Terhenniemi, Kehtolaulu Lemminkäiselle [Kołysanka dla Lemminkäinena], Sammon taonta [Wykuwanie Sampo].
\end{abstract}

Kalevala-sarja rozpoczęła w twórczości Klamiego poszukiwanie własnego stylu muzycznego i w istotny sposób wpłynęła na jego późniejsze utwory. Obecnie dzieło uważane jest za jedną z najbardziej znaczących fińskich kompozycji symfonicznych pierwszej połowy XX wieku i często określa się ją mianem „fińskiego Święta wiosny”. Artykuł przybliża sylwetkę twórcy, genezę i źródła inspiracji suity Kalevala-sarja oraz dokonuje krótkiej analizy poszczególnych części kompozycji pod kątem wpływów modernizmu europejskiego.

Słowa kluczowe: Uuno Klami; Kalewala; Igor Strawiński; Maurycy Ravel; muzyka fińska XX wieku. 
Uuno Klami (1900-1961) wraz z takimi twórcami jak Ernest Pingoud (1887-1942), Väinö Raitio (1891-1945) i Aare Merikanto (1893-1958) przynależy do pokolenia fińskiego modernizmu. Chociaż Pingoud, Raitio oraz Merikanto komponowali dzieła w stylu impresjonistycznym i ekspresjonistycznym, to styl tych twórców ma głębokie korzenie jeszcze w romantyzmie (Korhonen 1995: 44). Dopiero Klami był pierwszym kompozytorem fińskim, który pragnął zerwać z narodowo-romantycznym stylem muzyki Jeana Sibeliusa (1865-1957), pod którego głębokim wpływem w pierwszej połowie XX wieku pozostawała cała muzyka tego kraju (Howell 2006).

Będąc świadomym niebezpieczeństw związanych z badaniem terytorium, na którym Sibelius panował niepodzielnie, i zauważając, że wiele wcześniejszych wysiłków na tym obszarze skutkowało szarą i nieciekawą muzyką, przyjąłem zupełnie inne podejście (za: Korhonen 2007: 75) $)^{1}$.

Kompozytor po ukończeniu edukacji muzycznej w swoim rodzinnym kraju (1915-1924) wyjechał na dwuletnie studia do Paryża, gdzie zetknął się między innymi z Florentem Schmittem oraz prawdopodobnie z Maurycym Ravelem (Asikainen 1999: 123). Po powrocie z Paryża, w latach 1928-1929 kontynuował studia kompozytorskie w Wiedniu (Korhonen 1995: 59). To właśnie wyjazdy za granicę i zetknięcie się z modernizmem europejskim pomogły mu ukształtować swój własny styl, opozycyjny w stosunku do muzyki Sibeliusa.

Na temat postaci i twórczości Klamiego ukazało się wiele artykułów, przede wszystkim w języku fińskim. Część z nich została przytoczona w bibliografii na końcu artykułu. W Helsinkach działa aktywnie Uuno Klami Society, organizujące konferencje i sympozja poświęcone Klamiemu, które mają podkreślić jego doniosłą rolę w historii muzyki fińskiej. Najbardziej zasłużoną badaczką twórczości Klamiego jest Helena Tyrväinen, która opublikowała szereg artykułów na jego temat oraz obszerną pracę doktorską poświęconą wpływowi muzyki francuskiej na muzykę tego kompozytora: Kohti Kalevala-sarjaa Identiteetti, eklektisyys ja Ranskan jälki Uuno Klamin musiikissa (2013). W literaturze polskiej twórczość Klamiego nie wzbudziła zainteresowania badaczy - wyjątek stanowi krótki artykuł Asikainena (1999). Poniższy tekst ma na celu przybliżyć nieznaną twórczość fińskiego kompozytora polskiemu środowisku muzycznemu poprzez syntetyczne ujęcie wątków funkcjonujących już w literaturze obcojęzycznej. Na początku zostanie przedstawiona krótka charakterystyka utworów symfonicznych kompozytora powstałych podczas studiów w Paryżu. W kolejnych podrozdziałach autor skupi się na szczegółowej prezentacji suity Kalevala-sarja op. 23: genezy kompozycji, związków z muzyką Strawińskiego, po czym przejdzie do krótkiej analizy suity pod kątem wpływów modernizmu europejskiego. Głównym zamierzeniem artykułu jest ukazanie Kalevala-sarja jako dzieła przełomowego w historii muzyki fińskiej, które otwarło drogę do narodowego modernizmu.

\footnotetext{
${ }^{1}$ „Conscious of the dangers involved in exploring territory where Sibelius reigned supreme, and realizing that many previous efforts in that area had resulted in grey and uninteresting music, I took a wholly different approach". Wszystkie thumaczenia w artykule odautorskie - oryginalne cytaty podaję w przypisach dolnych.
} 


\section{Studia w Paryżu i odkrycie Kalewali}

Po I wojnie światowej Paryż był ulubionym miejscem studiów kompozytorów fińskich. Właściwie za wyjątkiem Aarre Merikanto, który nigdy go nie odwiedził, wszyscy starsi i młodsi kompozytorzy, począwszy od Jeana Sibeliusa, poprzez Oskara Merikanto, Leevi Madetoja, Erkki Melartina, Selim Palmgrena, aż do Väinö Raitio i Ernesta Pingoud, przebywali w nim krócej bądź dłużej (Tyrväinen 2003: 77). Podczas studiów w stolicy Francji w latach 1924-1925 Klami zapoznał się z muzyką Sergiusza Prokofiewa, Maurycego Ravela, Igora Strawińskiego i Manuela de Falli oraz po raz pierwszy zaczął studiować narodowy fiński epos - Kalewalę.

Komponowanie muzyki do tematów zaczerpniętych z Kalewali nie jest obecnie aktualnym tematem w Finlandii, a przynajmniej nie jakoś powszechnie... Sądzę, że jeśli temat ten znów się pojawi, to wydarzy się to pod zupełnie innymi gwiazdami i innymi ideałami (Inspired by Tradition 2005: 87) 2 .

Rosyjscy moderniści, tacy jak Prokofiew i Strawiński, i nowa muzyka hiszpańska wstrząsnęli mną od stóp do głów. [...] Stało się to w tym czasie, gdy poszedłem do Sorbony wypożyczyć kopię Kalewali (Virtanen 1945: 613-614).

Odtąd kompozytor poszukiwał tematu zaczerpniętego z Kalewali, który mógłby wykorzystać jako program do nowego utworu symfonicznego. Pierwszą ważną kompozycją okazała się Karjalainen rapsodia op. 15 [Rapsodia Karelska] (1927), której materiał i sposób jego opracowania okazują się mieć wiele wspólnego ze Świętem wiosny (Tyrväinen 2013: 410-431). W Karjalainen rapsodia Klami po raz pierwszy przeciwstawił się fińskiemu romantyzmowi, chociaż dzieło to nie posiada związków z mitologią Kalewali. Kompozytor wykorzystał oryginalny, nieprzetworzony materiał zaczerpnięty z karelskiej muzyki ludowej oraz bogatą paletę brzmień orkiestrowych charakterystyczną dla stylu impresjonistycznego Ravela. Po tej kompozycji powstało wiele dzieł symfonicznych napisanych w celach zarobkowych dla Fińskiej Orkiestry Radiowej: Symphonie enfantine op. 17 [Symfonia dziecięca] (1915) na małą orkiestrę, Hommage à Handel op. 21 (1931) na instrumenty smyczkowe i fortepian, Merikuvia op. 22 [Obrazy morskie] (1930-1932) oraz orkiestrowa sześcioczęściowa suita Tšeremissiläinen fantasia op. 19 na wiolonczelę i orkiestrę (1931) (Korhonen 1995: 59-60). Przełom w karierze Klamiego nastąpił dopiero z następnym dziełem Kalevala-sarja op. 23 [Suita z Kalewali].

\section{Geneza suity Kalevala-sarja}

W latach 20. XX wieku kariera Klamiego w Finlandii zaczęła się dynamicznie rozwijać pod auspicjami wybitnego fińskiego dyrygenta Roberta Kajanusa (1856-1933). Kajanus

\footnotetext{
${ }^{2}$,Writing music to Kalevala subjects is not really a current topic in Finland today, not in any extensive way at least... I believe that if it comes around again, it will happen under different stars and different ideals".

${ }^{3}$ „Russian Modernists such as Prokofiev and Stravinsky and new Spanish music, shook me up from top to toe. [...] It was around that time that I went to the Sorbonne to borrow a copy of the Kalevala". Tłumaczenie z języka fińskiego na angielski (Korhohen 2007: 72).
} 
był założycielem i głównym dyrygentem Helsińskiej Orkiestry Filharmonicznej i znaczącą postacią w ówczesnym fińskim środowisku muzycznym. Bardziej niż ktokolwiek w swoim kraju był odpowiedzialny za budowanie narodowej kultury muzycznej (Korhonen 2007: 29-30). Finlandia rok przed Polską, a więc w 1917 roku, odzyskała niepodległość po okresach borykania się z przynależnością do Szwecji i Rosji. Stąd tak ważne dla Finów w tym czasie było ukształtowanie nowej, świeżej - choć jednocześnie wyrastającej z tradycji - kultury, sztuki i muzyki. Ambicją Kajanusa było wyszukiwanie młodych talentów kompozytorskich, które sprostałyby temu zadaniu.

W latach 20. Kajanus zwrócił się do Klamiego z zamówieniem na napisanie kompozycji opartej na Kalewali, co okazało się jednak w tym czasie zbyt wielkim wyzwaniem dla młodego dwudziestoparoletniego kompozytora. Dopiero dekadę później pod przemożnym wpływem Święta wiosny Strawińskiego Klami przystąpił do komponowania wielkiego dzieła wokalno-instrumentalnego, które ostatecznie ukończył po wielu latach długiego i skomplikowanego procesu tworzenia (Korhonen 1995: 60).

Początkowo kompozytor planował napisać oratorium Kalevala Oratorio, i naszkicował szesnaście obrazów (tableaux) dla solistów, chóru, organów i orkiestry symfonicznej (Korhonen 2007: 75). Pierwszy z nich, Maan synty [Stworzenie Ziemi], został wykonany w 1932 roku, ale już w tym czasie Klami zmienił pierwotny zamysł całego utworu (Korhonen 2007: 75). Zdecydował się na napisanie dzieła scenicznego przeznaczonego na zakończenie wieczoru w formie antycznej greckiej tragedii, z narratorem, zespołem baletowym, w których osiemnaście obrazów miało przedstawiać bohaterów i wydarzenia z Kalewali (Tyrväinen 1997: 210). Skomponował cztery części, których prawykonanie odbyło się w 1933 roku pod nazwą „Choreograficzne obrazy z Kalewali” (Inspired by tradition 2005: 94). Następnie dopisał scherzo, które miało pierwotnie rozdzielać cztery skomponowane części, ale w trakcie pracy tak się ono rozrosło, że postanowił stworzyć z niego niezależną kompozycję Lemminkäisen seikkailut saaressa op. 25 [Przygody Lemminkäinena na wyspie]. W 1943 roku zrewidował wszystkie części suity i napisał środkowe ogniwo: Terhenniemi, jako rodzaj scherza-intermezza (Korhonen 2007: 75).

\section{Inspiracje Ś więtem wiosny Strawińskiego}

Pierwsza wersja kompozycji z 1933 roku jest bliższa Święcie wiosny Strawińskiego niż wersja ostateczna (Tyrväinen 1997: 208). Wydaje się to zrozumiałe w kontekście gwałtownego w tym czasie buntu kompozytora przeciwko hegemonii stylu Sibeliusa w Finlandii. Klami pragnął odciąć się od wielkiego mistrza, co okazało się możliwe dzięki awangardowemu stylowi rosyjsko-francuskiego Strawińskiego. Wydaje się, że Klami potrzebował muzyki Strawińskiego, aby przemówić swoim własnym głosem. W pierwszej wersji utworu w otwierającej części Maan synty kompozytor wprowadził długie ostinato bliźniaczo podobne do ostinata z Wróżb wiosennych i tańców dziewczą ze Święta wiosny. W późniejszej wersji zostało ono wykreślone i stało się zalążkiem motywicznym całego utworu (przykłady 1 i 2). 
Przykład 1. Uuno Klami, Kalevala-sarja, Maan synty, motyw ostinatowy w puzonach, numer 7 w partyturze.

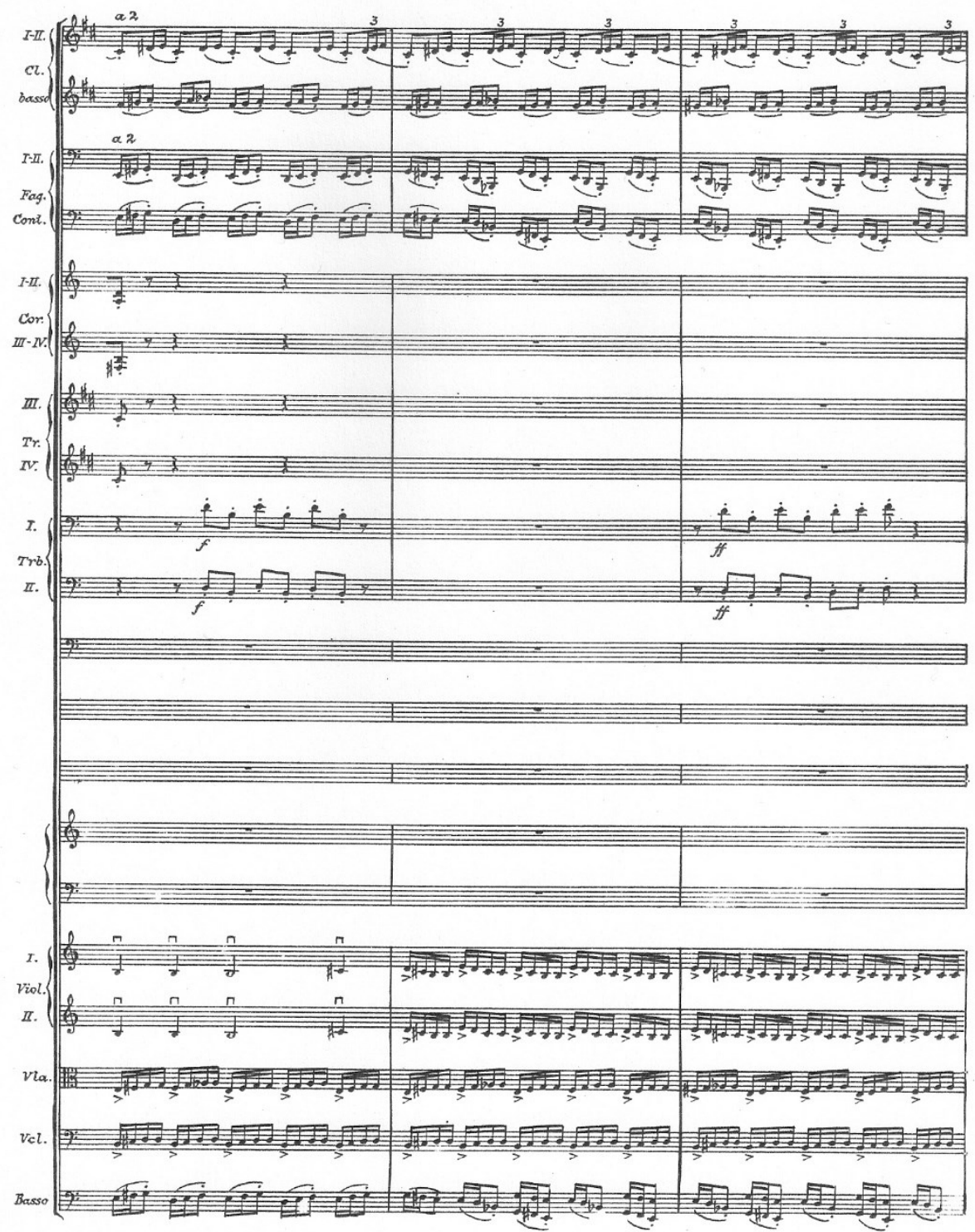

Przykład 2. Igor Strawiński, balet Święto wiosny, Wróżby wiosenne i tańce dziewcząt, motyw ostina-towy w pierwszych skrzypcach.

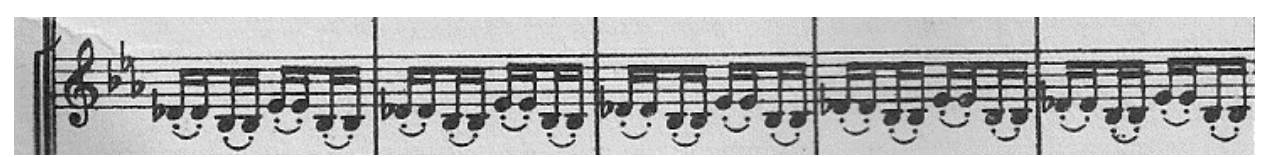


We wczesnej wersji Klami nie zastosował cytatów z muzyki ludowej, jak zrobił to Strawiński w swoim Święcie wiosny (Taruskin 1980). „Takie nowe użycie muzyki ludowej było ze swojej natury bardziej sprawą międzynarodową niż narodową, stąd nacisk [u Klamiego] został położony raczej na potędze natury i jej prymitywnych siłach, niż na indywidualnych cechach narodowych" (Salmenhaara 1990: 60-61) ${ }^{4}$. Prawdą jest, że Klami nigdy nie stworzył stylistycznej syntezy, tak jak to uczynili Bartók czy Strawiński, nigdy też dogłębnie nie studiował fińskiej muzyki ludowej (Tyrväinen 1997: 202).

Ostateczna wersja utworu wydaje się dużo bardziej osobista niż wersja pierwsza. Jednak i w niej wyczuwalne są wpływy i podobieństwa do Święta wiosny, są one jednak dużo subtelniejsze i trudniej dostrzegalnie niż w wersji pierwotnej. Nie zależało Klamiemu na zasymilowaniu tego, co jest albo nie jest rosyjskie w muzyce Strawińskiego. Jak pisze Tyrväinen, „nie był w stanie sprecyzować, co w muzyce Strawińskiego było rosyjskie, a co nowoczesne. Niemniej jednak był zafascynowany jej brzmieniem" (1997: 207)5. Posłużył się raczej stylem i technikami Strawińskiego, aby skomponować swoją własną muzyczną wizję pogańskiego świata Kalewali.

Jakkolwiek w orkiestracji Klamiego pojawia się wiele elementów zaczerpniętych ze Święta wiosny, partytura Kalavala-sarja jest dużo bardziej konwencjonalna w porównaniu z dziełem rosyjskiego kompozytora. Fiński twórca nie stosuje agresywnych ataków dźwięków, „krzyku blachy”, metro-rytmicznych komplikacji i przesunięć akcentów oraz ostrych dynamicznych kontrastów. Sam koloryt utworu jest dużo bardziej stonowany i Kalavala-sarja nie brzmi tak „,barbarzyńsko” jak Święto wiosny ${ }^{6}$. Podłoże harmoniczne jest w wielu wypadkach bardzo tradycyjne.

\section{Krótka analiza poszczególnych części suity}

Podczas gdy Święto wiosny Strawińskiego jest dwuczęściowym baletem, suita Kalevalasarja jest dziełem wyłącznie symfonicznym i składa się z pięciu części: Maan synty [Stworzenie Ziemi], Kevään oras [Kiełki wiosny], Terhenniemi, Kehtolaulu Lemminkäiselle [Kołysanka dla Lemminkäinena], Sammon taonta [Wykuwanie Sampo]. Kompozytor napisał krótki program omawiający poszczególne części kompozycji, który został wydrukowany jako przedmowa do partytury utworu (Klami 1981: 2).

\section{Część I}

Program pierwszej części, zatytułowanej Maan synty [Stworzenie Ziemi], jest oparty na pierwszej pieśni Kalewali, która opisuje wyłanianie się Ziemi z chaosu. Sam początek wydaje się jednak bliższy brzmieniowo Rapsodii hiszpańskiej Ravela (1907) niż Świętu wiosny

\footnotetext{
${ }^{4}$,This new use of folk music is by nature an international matter than a national one, the emphasis being on the force of nature and primitive strength rather than on individual national qualities".

${ }^{5}$ „Klami was unable to be specific about what was Russian in Stravinsky`s music and what was modern in it. Neverthless, he was fascinated by its sound".

${ }^{6}$ Warto w tym miejscu zauważyć, że czas trwania obu utworów jest podobny i wynosi około trzydzieści minut.
} 
(przykład 3). Rozwibrowane dźwięki w pierwszych skrzypcach i wiolonczelach wraz z pojedynczymi uderzeniami harfy i subtelnymi alikwotami drugich skrzypiec tworzą mistyczną atmosferę mroku przypominającą Prelude à la Nuit z Rapsodii hiszpańskiej Ravela (przykład 4) bądź Noce w ogrodach Hiszpanii de Falli. Dopiero na przestrzeni taktów 14-16, w partii rogów pojawia się motyw sygnałowy analogiczny do słynnego motywu myśliwskiego z Zabawy w porywanie (Jeu du Rapt) Strawińskiego (przykład 5). Rozwijająca się od numeru $7 \mathrm{w}$ partyturze energiczna linia melodyczna w smyczkach i instrumentach dętych blaszanych przypomina wspomniany już motyw ostinatowy z Tańca dziewcząt. Aby nadać mu bardziej dynamicznego charakteru, Klami wykorzystuje akordy na słabą część taktu (przykład 6).

Przykład 3. Uuno Klami, Kalevala-sarja, początek Maan synty.

KALEVALA-

sarja - svit - suite

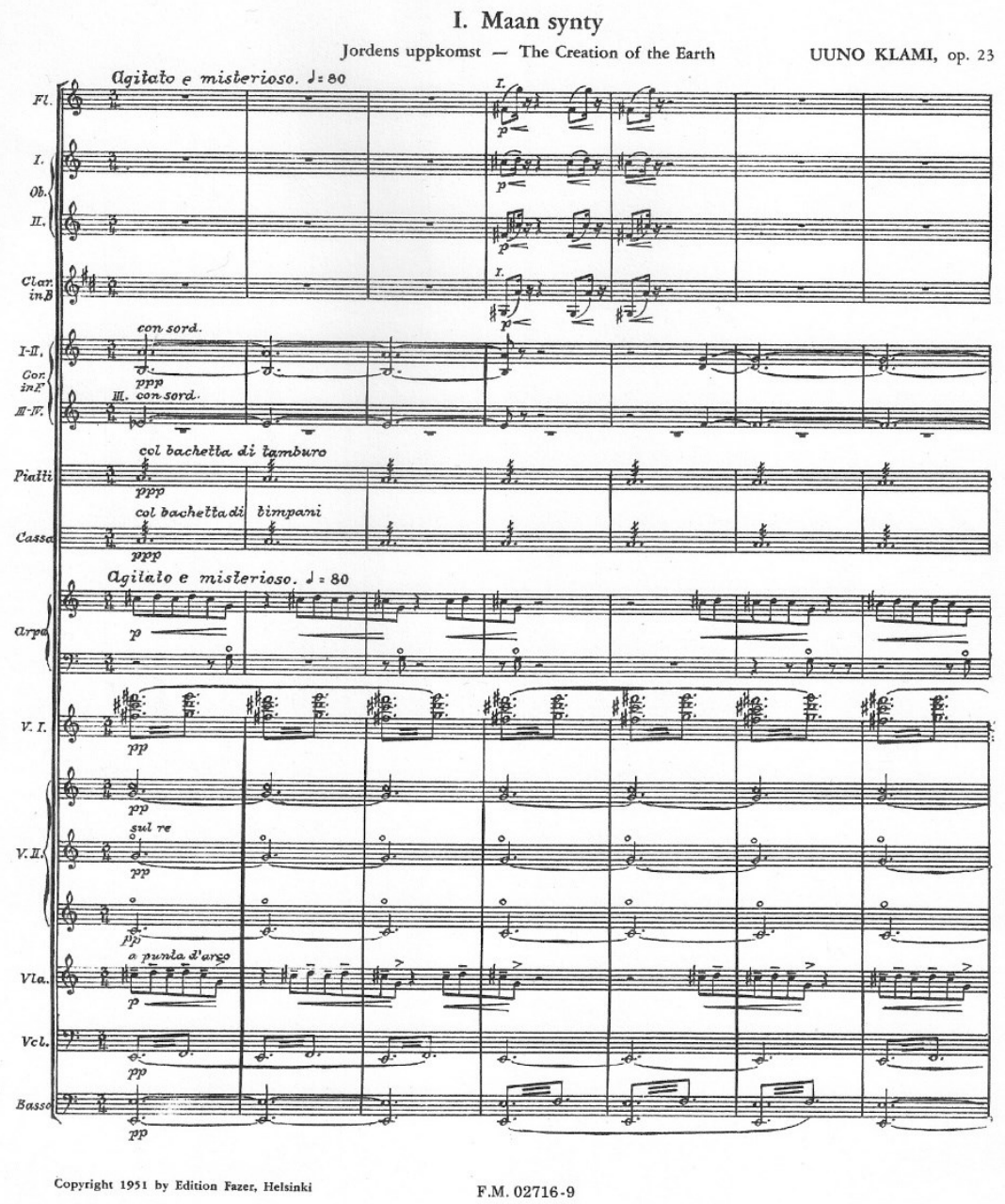


Przykład 4. Maurycy Ravel, Rapsodia hiszpańska, Prelude à la Nuit, początek.

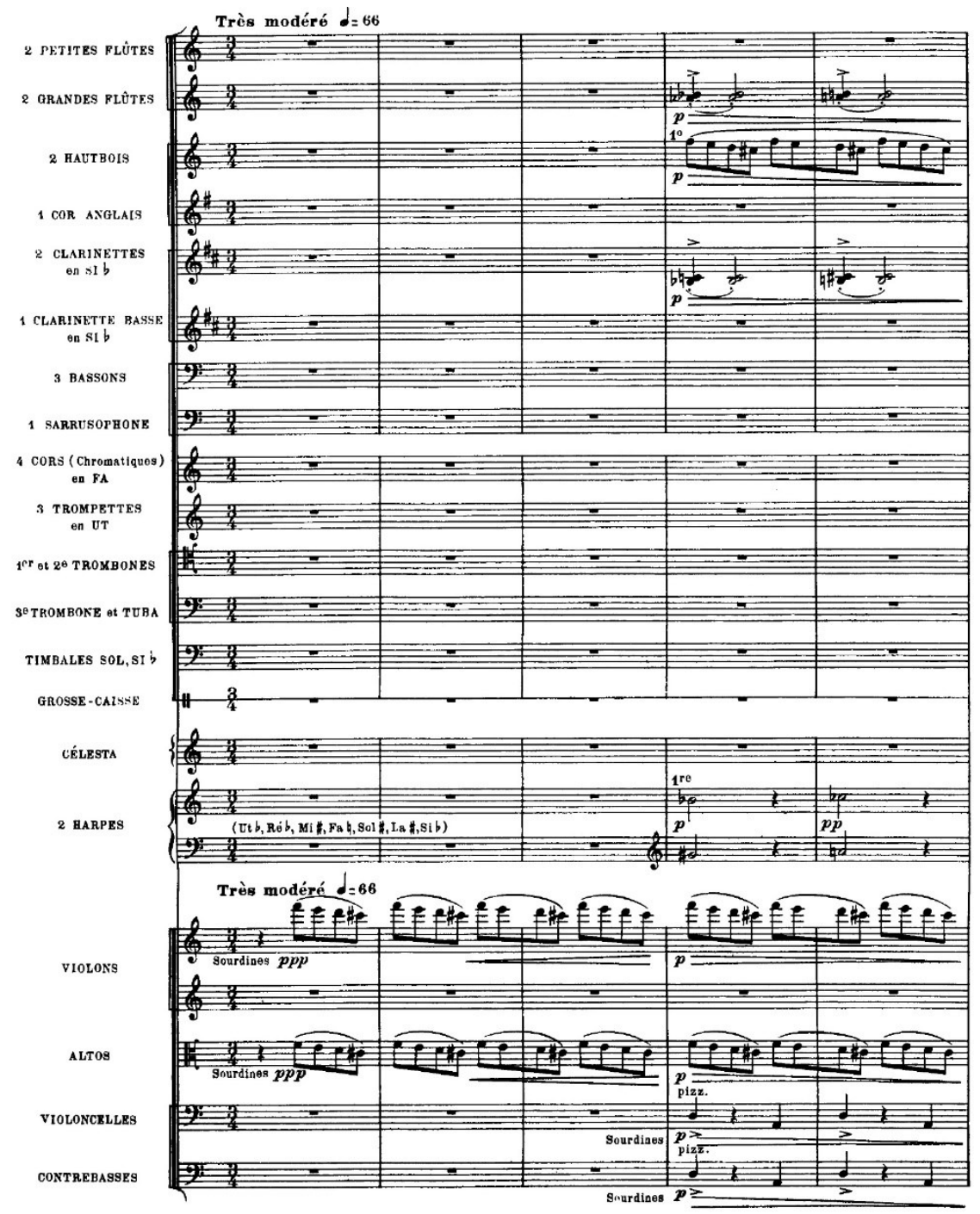


Przykład 5. Uuno Klami, Kalevala-sarja, Maan synty, motyw sygnałowy w rogach.

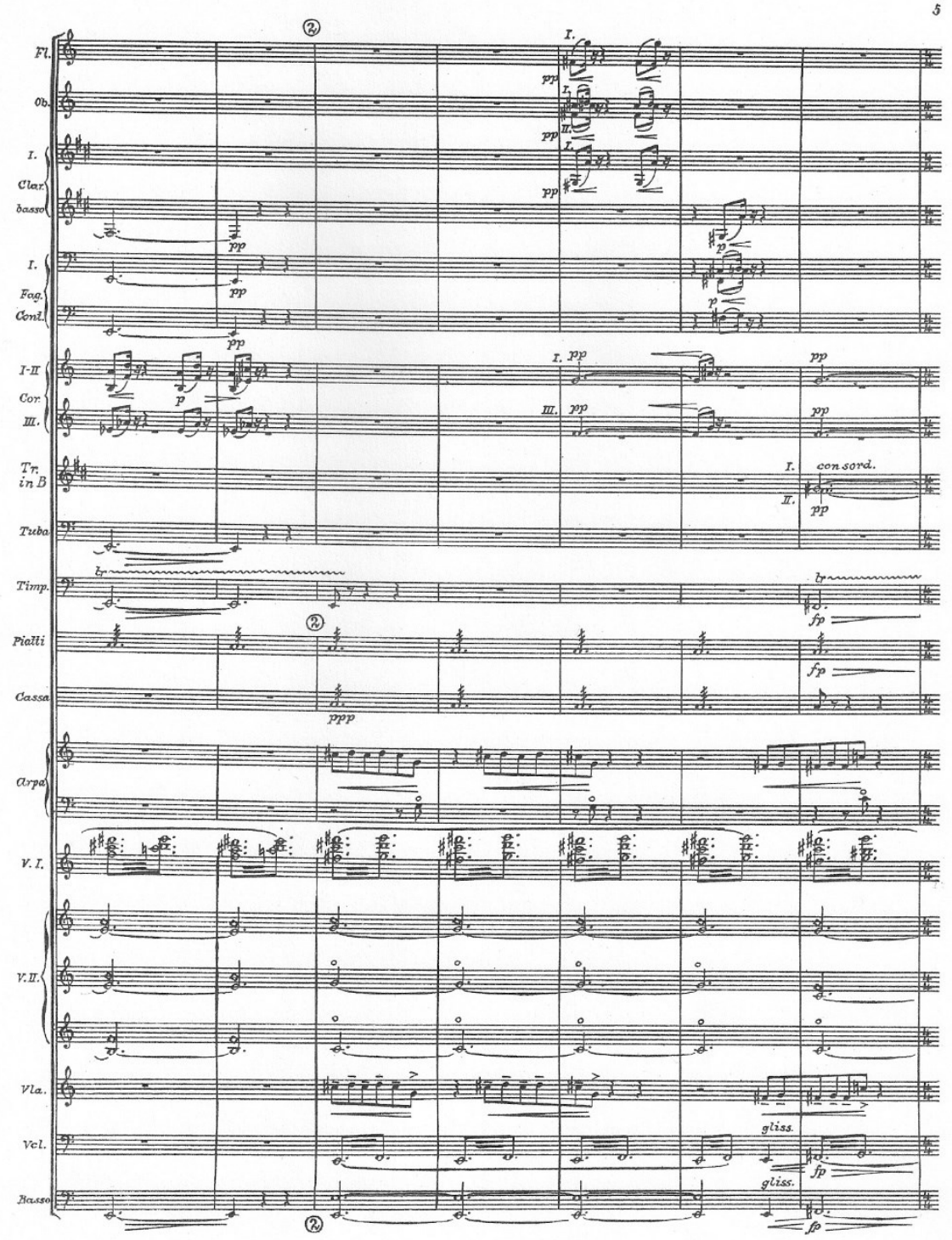


Przykład 6. Uuno Klami, Kalevala-sarja, Maan synty, motyw ostinatowy w smyczkach.

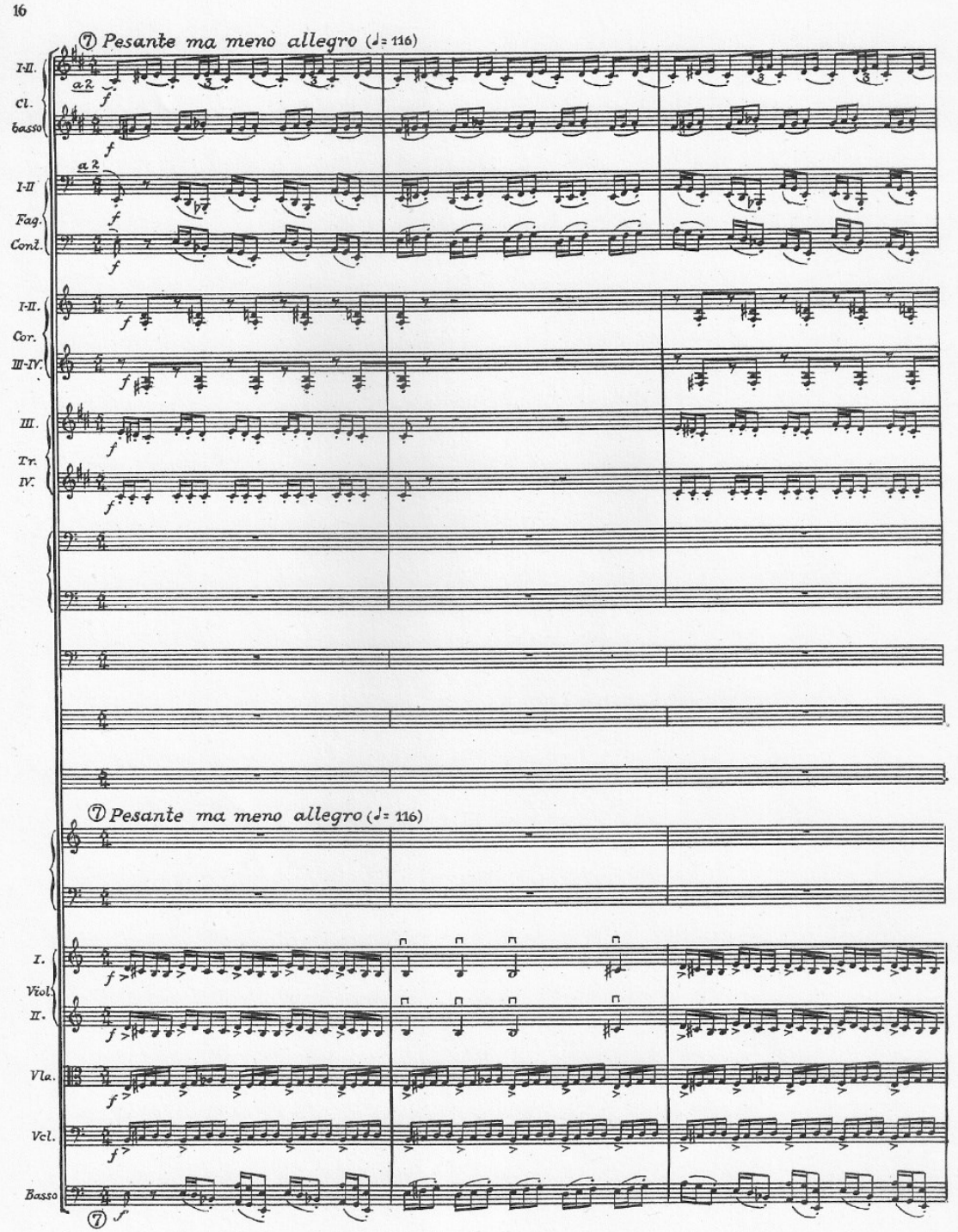

\section{Część II}

Cześć druga - Kevään oras [Kiełki wiosny] - jest opisana przez kompozytora w następujących słowach: „Legendarny bohater Väinämöinen sieje ziarno, które wyrasta z ziemi i kwitnie” (Klami 1981: 2) ${ }^{7}$. Główny temat tej części jest powierzony rogowi i przypomina

\footnotetext{
${ }^{7}$ „The legendary hero Väinämöinen sows a seed, which sprouts from the earth and grows blossoms”.
} 
analogiczną melodię z finału baletu Ognisty ptak Strawińskiego (przykłady 7 i 8). Niektóre fragmenty Kevään oras zbliżają się brzmieniowo do jarmarcznej muzyki z baletu Pietruszka Strawińskiego poprzez wykorzystanie wysokich rejestrów instrumentów drewnianych.

Przykład 7. Igor Strawiński, balet Ognisty ptak, final, pojedyncza linia melodyczna rogu.

160 Lento maestoso $d=54$

161

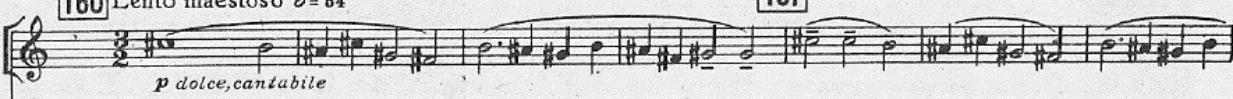

Przykład 8. Uuno Klami, Kalevala-sarja, Kevään oras, pojedyncza linia melodyczna rogu.

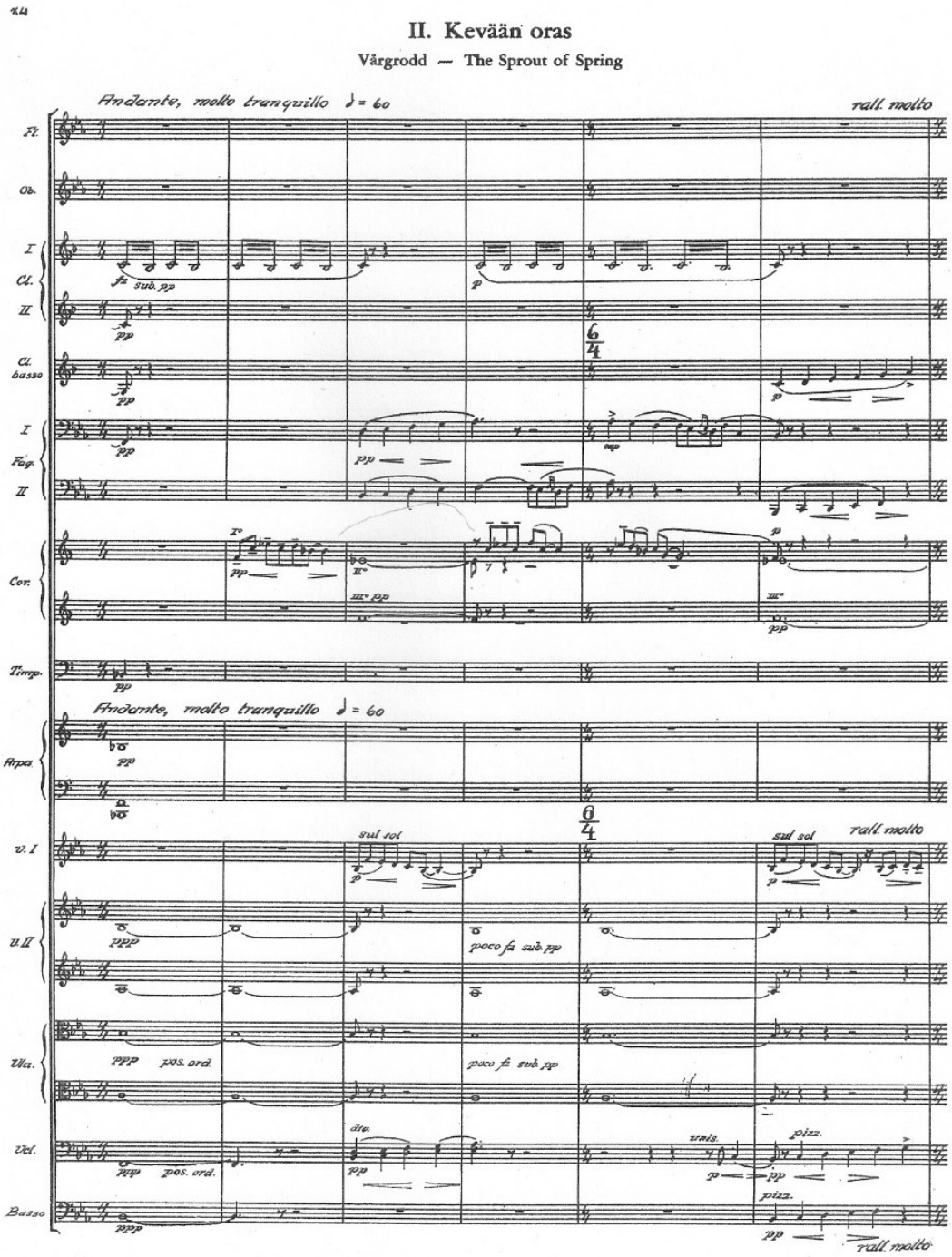




\section{Część III}

Trzecia część - Terhenniemi - według słów kompozytora ma tworzyć „,mityczną atmosferę poprzez swawolne, taneczne rytmy" (Klami 1981: 2) ${ }^{8}$. Trzynutowe ostinato grane przez altówki, a następnie wiolonczele palcami (pizzicato) przywodzą na myśl Taniec piekielny Kościeja z baletu Ognisty ptak Strawińskiego. Ponad tym motywem Klami wprowadza w smyczkach i instrumentach dętych drewnianych linie melodyczne, które są stylizacją fińskiej muzyki ludowej, ale nie są oryginalnymi melodiami ludowymi. Opierają się na trzech, czterech dźwiękach, a ich struktura jest wewnętrznie powtarzana (przykład 9). Poprzez wykorzystanie prostych linii, które mają na celu przywołać atmosferę czasów pogańskich, melodyka Klamiego zbliża się do melodyki Święta wiosny Strawińskiego.

Przykład 9. Uuno Klami, Kalevala-sarja, Terhenniemi, trzydźwiękowe ostinato w altówkach, klarnetach, wiolonczeli i kontrabasach oraz stylizowana linia melodyczna we flecie.
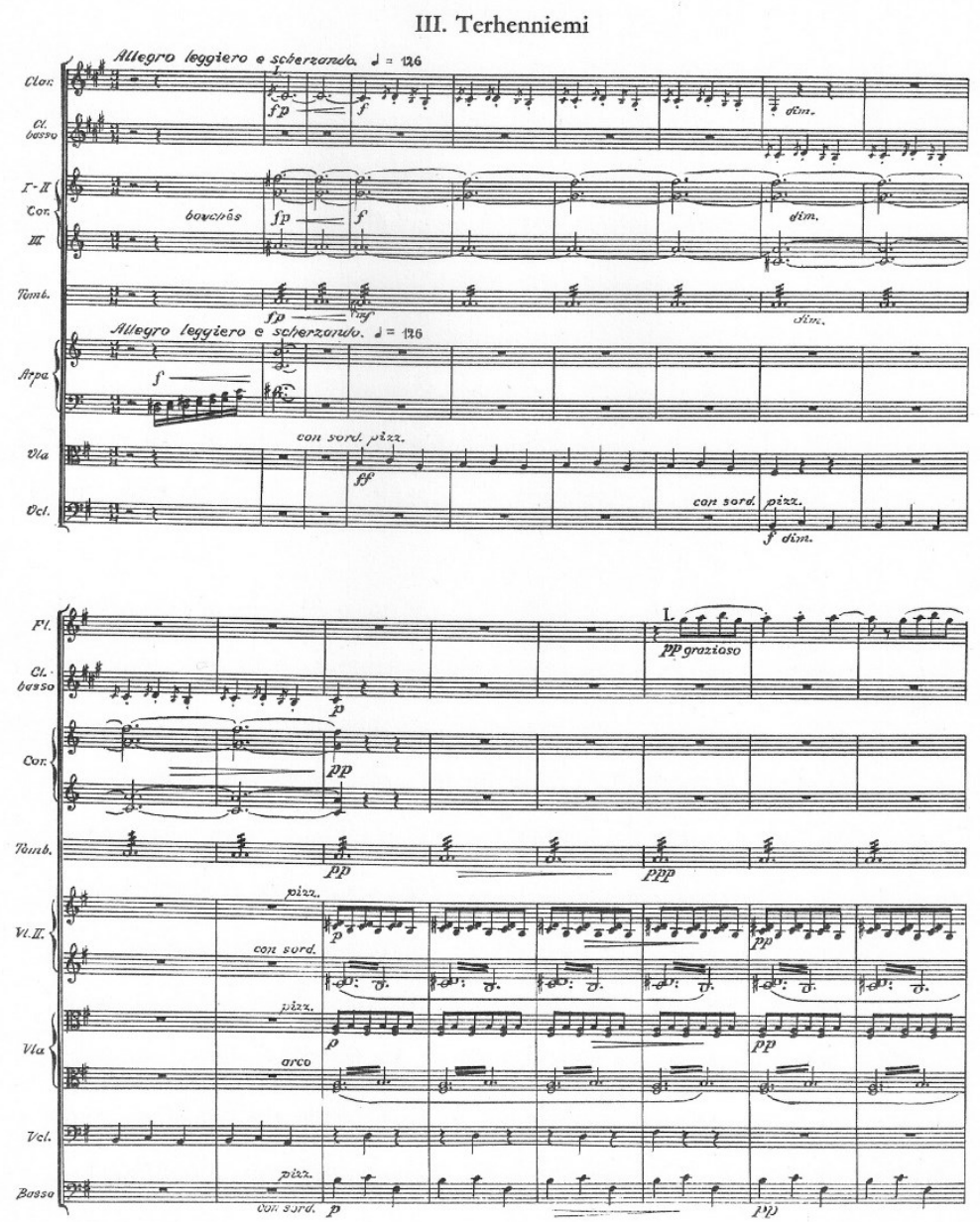

\footnotetext{
${ }^{8}$ „A mythical atmosphere is created by frolicsome dance rhythms”.
} 


\section{Część IV}

Czwarta część suity - Kehtolaulu Lemminkäiselle [Kołysanka dla Lemminkäinena] - jest napisana w najbardziej osobistym stylu kompozytora. Matka Lemminkäinena śpiewa przejmującą pieśń dla syna, którego dzięki magii ocaliła z rzeki śmierci Tuoneli i przywróciła do życia. Charakter tej części jest nostalgiczny, typowy dla późniejszych dzieł Klamiego. Ten typ melancholii łączy się z zastosowaniem opadających linii melodycznych charakterystycznych dla niektórych dzieł Sibeliusa, zwłaszcza Łabędzia z Tuoneli op. 22 nr 3. Co więcej, część ta zbliża się do neoromantycznego języka Sibeliusa w wyniku wykorzystania we wspólnym dla Klamiego i Sibeliusa temacie rzeki śmierci Tuoneli krótkich motywów melodycznych w partii rożka angielskiego (por. przykłady 10 i 11). Typ brzmienia z Kehtolaulu Lemminkäiselle antycypuje napisaną później przez Klamiego fantazję symfoniczną Revontulet (Aurore boréale) op. 38.

Przykład 10. Uuno Klami, Kalevala-sarja, początek Kehtolaulu Lemminkäiselle.

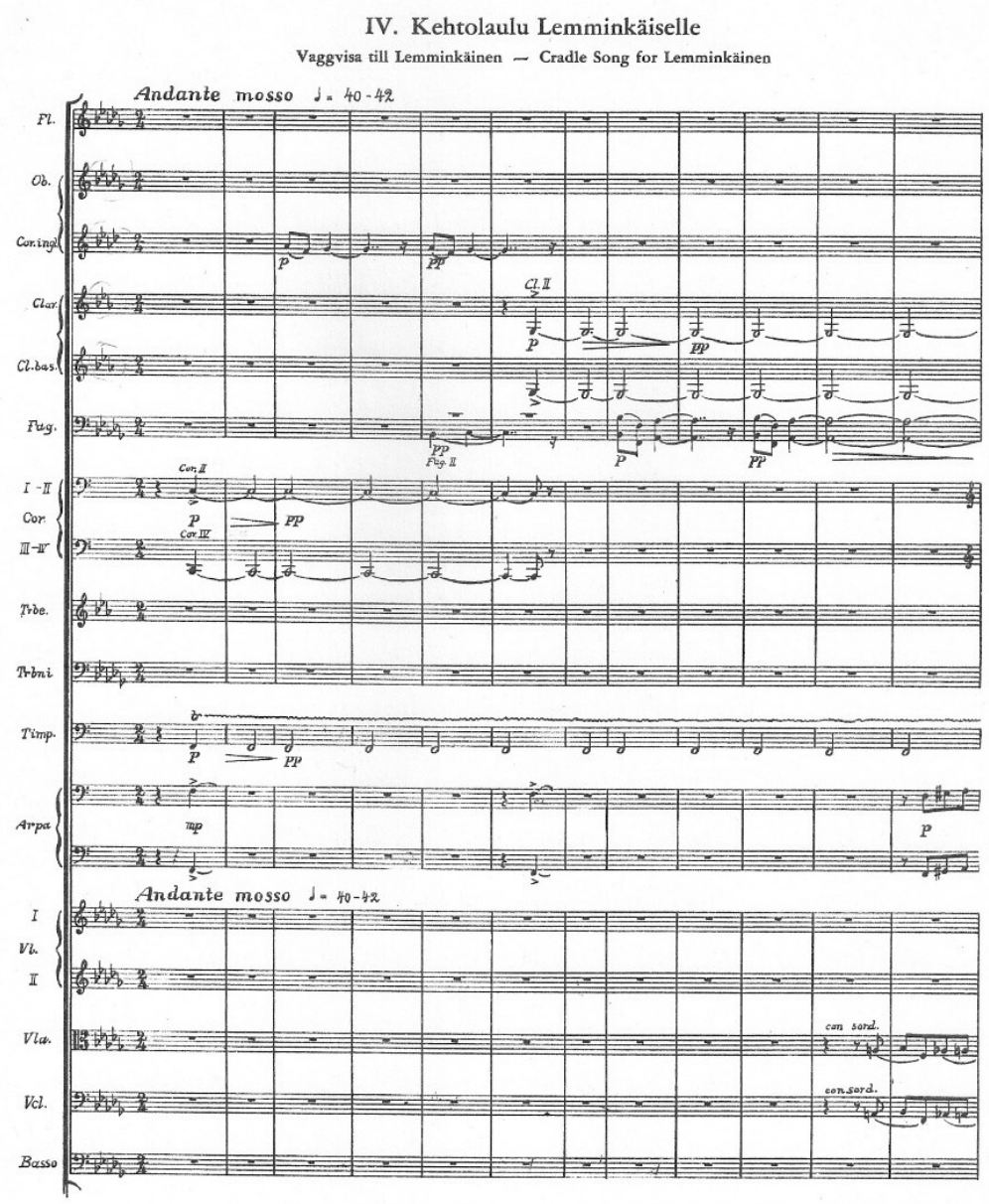


Przykład 11. Jean Sibelius, Labędźz z Tuoneli, początek.

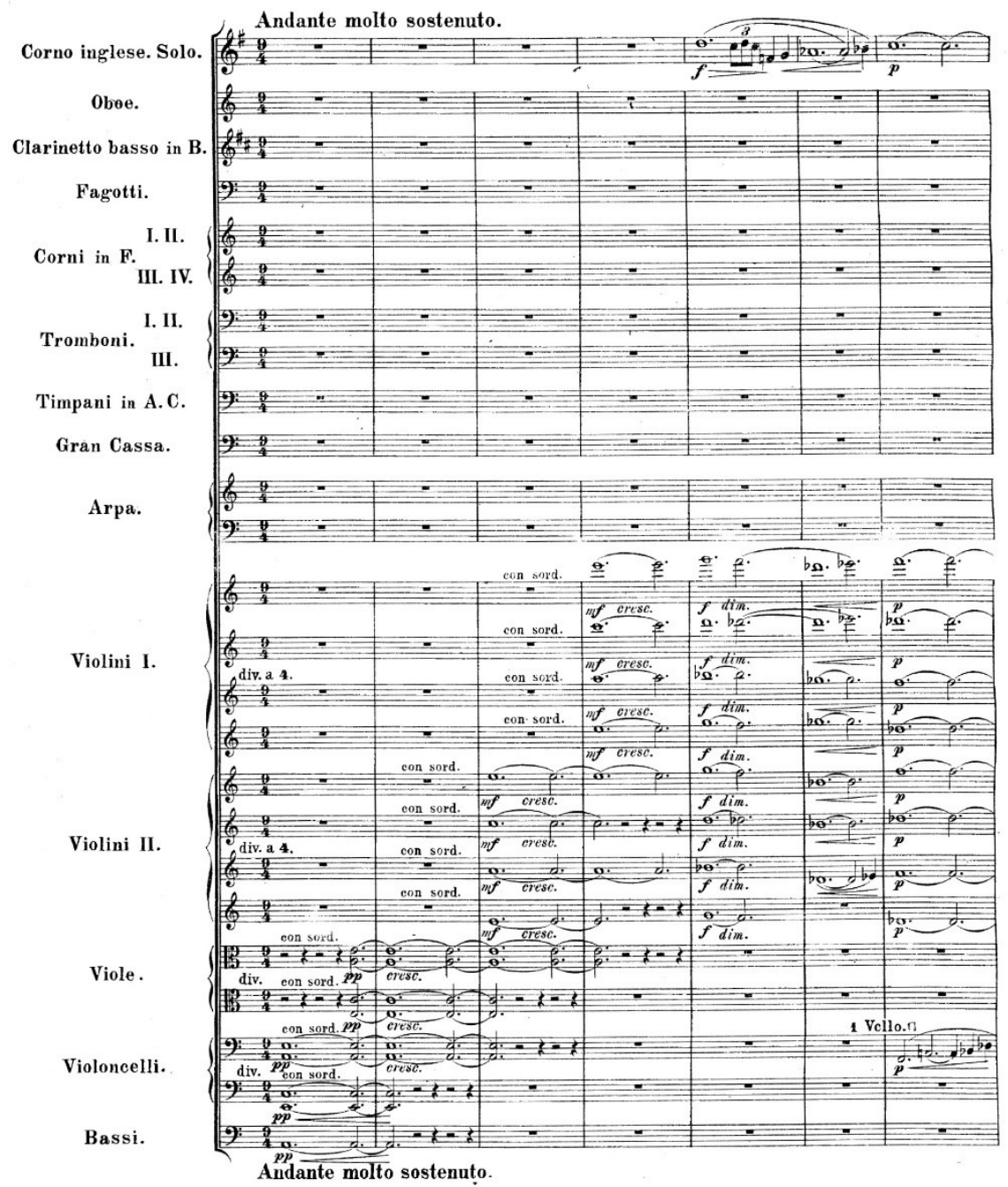

\section{Część V}

Finał Kalavala-sarja, zatytułowany Sammon taonta [Wykuwanie Sampo], oparty jest na historii mitycznego kowala Ilrmarinena. Wykuwa on Sampo, magiczny instrument, który staje się przyczyną niezgody pomiędzy ludami zamieszkującymi północ i południe Finlandii. Jak pisze sam Klami w przedmowie do tej części: ,[Sampo] był to baśniowy narodowy skarb starodawnego fińskiego ludu Kalewali” (Klami 1981: 2) ${ }^{9}$. Aby przedstawić wykuwanie czarodziejskiego młynka szczęścia Klami, zastosował ostinata w metalowych

\footnotetext{
${ }^{9}$ „It was a fabulous national treasure to the ancient Finnish folk of the Kalevala”.
} 
instrumentach perkusyjnych (dzwony, trójkąt, tam-tam, talerze). Osiągnął także kulminację, która może być porównywalna z tą, jakiej użył Strawiński w Korowodach wiosennych (przykład 12). Wydaje się jednak, że sam akompaniament orkiestrowy bardziej przypomina styl Rimskiego-Korsakowa niż nowatorskie brzmienia Święta wiosny Strawińskiego.

Przykład 12. Uuno Klami, Kalevala-sarja, Sammon taonta, kulminacja części.

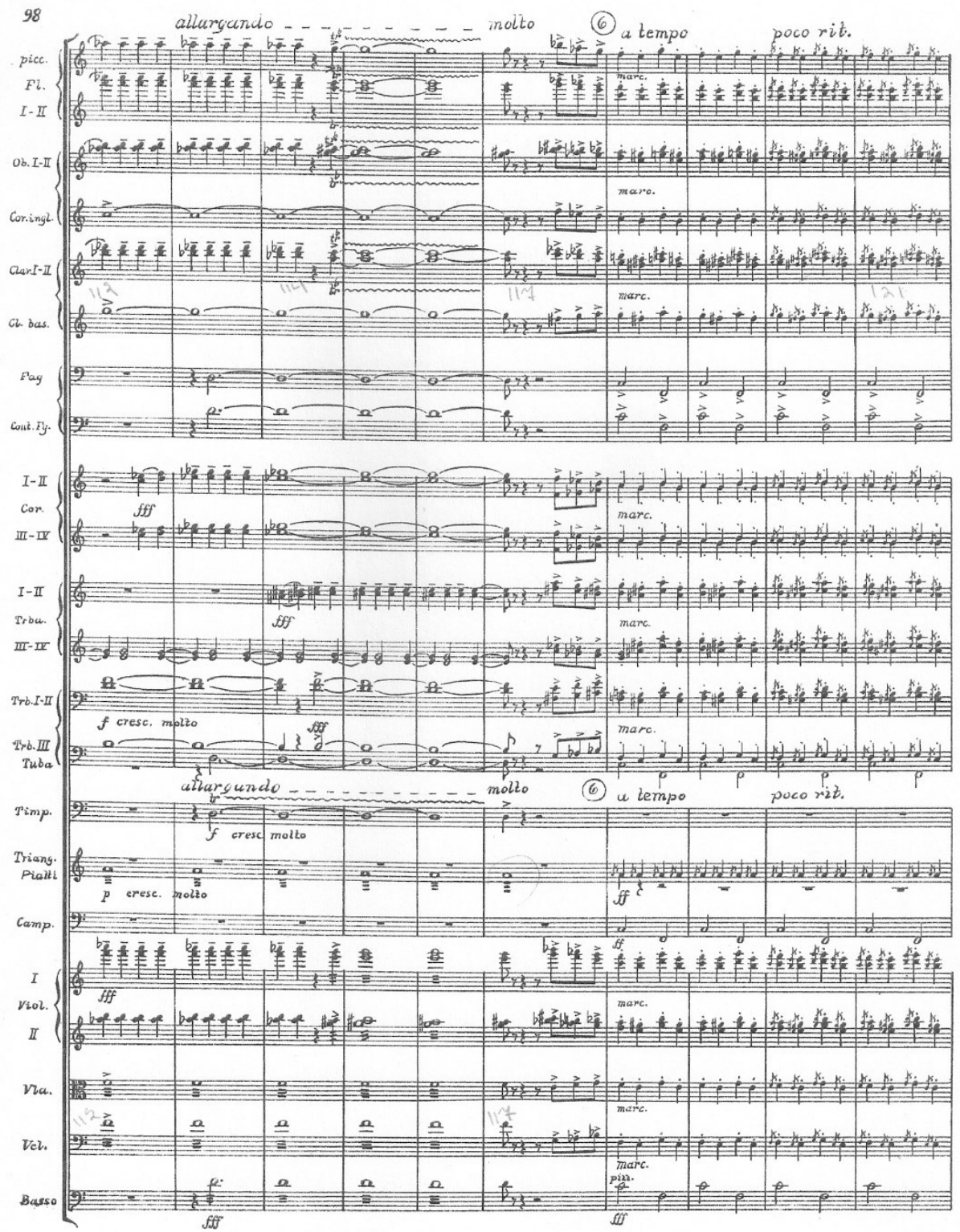




\section{Zakończenie}

Kalevala-sarja op. 23 [Suita z Kalewali] nie jest pierwszym ani ostatnim utworem napisanym pod wpływem Strawińskiego, Ravela i de Falli. W 1933 roku fiński muzykolog i dyrygent Toivo Haapanen zauważył podobieństwa pomiędzy stylem Klamiego a muzyką „francusko-rosyjskiego Strawińskiego, hiszpańskiego de Falli oraz węgierskiego Bartóka" (za: Salmenhaara 1990: 60-61) ${ }^{10}$. Zastanawiającym jest, dlaczego Klami zainteresował się fińską mitologią i muzyką ludową dopiero wówczas, kiedy wyjechał do Paryża? Prawdopodobnie przebywanie w fascynującym środowisku stolicy Francji otworzyło go na nową muzykę oraz zdjęło z niego ciężar i piętno muzyki Sibeliusa, jakie musiał odczuwać w rodzimej Finlandii (Howell 2006).

Bardzo łatwo zrozumieć, dlaczego Klami wybrał tematy zaczerpnięte z Kalewali. Podobnie jak Strawiński fiński twórca pragnął powrócić do czasów dawnej pogańskiej kultury, pełnej rytuałów i legend. Zdecydował się napisać rodzaj „fińskiego Święta wiosny” w porównywalny sposób do rosyjskiego Święta wiosny i zerwać z usankcjonowaną tradycją muzyczną w traktowaniu tematów zaczerpniętych z Kalewali.

Można śmiało zaryzykować stwierdzenie, że Kalavala-sarja rozpoczyna się od faktury i stylu charakterystycznego dla Ravela (Prelude à la Nuit z Rapsodii hiszpańskiej) i de Falli (Noce w ogrodach Hiszpanii), w części drugiej i trzeciej pojawiają się inspiracje baletami Ognisty ptak i Pietruszka Strawińskiego, następnie romantyczna narracja z typowym ciemnym kolorytem stylu Sibeliusa w części czwartej (analogia z Łąbędziem z Tuonelii), a cały utwór kończy na prymitywnej w swoim charakterze i rytmie muzyce typowej dla Święta wiosny Strawińskiego.

Jak zauważyła Tyrväinen w Kalavala-sarja „,...] nieromantyczna artystyczna wizja, pomysłowa, odważna wirtuozeria orkiestrowa niesłyszana przedtem w muzyce fińskiej oraz dopracowane wykończenie utworu - wszystkie one cechują nowy, oryginalny i europejski wkład w muzykę Finlandii” (Tyrväinen 1997: 210) ${ }^{11}$. Poprzez zespojenie różnych elementów z muzyki zachodniego modernizmu udało się Klamiemu odejść od narodowego romantyzmu Sibeliusa i stworzyć swój własny, charakterystyczny idiom. Kalavala-sarja nie osiągnęła tak wielkiego sukcesu jak dzieła Sibeliusa, stanowi jednak kamień milowy w rozwoju muzyki fińskiej. Zachęciła nowych, młodych kompozytorów do poszukiwania własnego języka muzycznego i oryginalności (Inspired by Tradition 2005: 91).

\footnotetext{
10 „The Franco-Russian Stravinsky, the Spanish de Falla and the Hungarian Bartók”.

${ }^{11}$ „The non-romantic artistic vision, the imaginative, fearless orchestral virtuosity, unheard in Finnish music before this piece, and the elaborate refinement of piece - all these together mark a thoroughly new, original and European contribution to the music of Finland".
} 


\title{
Bibliografia
}

Asikainen, M. 1999. Selim Palmgren i Uuno Klami - przedstawiciele „nurtu francuskiego” w muzyce fińskiej na początku XX wieku. Res Facta Nova, 3(12): 119-126.

Howell, T. 2006. After Sibelius. Studies in Finnish Music. Aldershot: Ashgate Publishing Ltd.

Inspired by Tradition. Kalevala Poetry in Finnish Music. 2005. Jyväskylä: Finnish Music Information Centre.

Klami, U. 1981. Kalevala-sarja, partytura utworu. Helsinki: Edition Fazer.

Korhonen, K. 2007. Inventing Finnish Music. Jyväskylä: Finnish Music Information Centre.

Korhonen, K. 1995. Finnish Orchestral Music 1. Jyväskylä: Finnish Music Information Centre.

Tyrväinen, H. 2013. Kohti Kalevala-sarjaa - Identiteetti, eklektisyys ja Ranskan jälki Uuno Klamin musiikissa. Helsinki: Acta Musicologica Fennica 30.

Tyrväinen, H. 2003. Influence of France on the Music of Uuno Klami - Outlines up to the Second World War. W: H. Tyrväinen, red. Symposion Uuno Klami 1900-2000: 77-101. Helsinki: Sibelius Academy \& Uuno Klami Society.

Tyrväinen H. 1997. The Solitary Way of Uuno Klami in the Finnish Music of the $20^{\text {th }}$ Century. Folklorism, Nationalism, Neoclassicism. W: T. Mäkelä, red. Music and Nationalism in $20^{\text {th }}$ century Great Britain and Finland: 199-216. Hamburg: von Bockel Verlag.

Ranta, S. 1945. Suomen Säveltäjiä. Helsinki: WSOY.

Taruskin, R. 1980. Russian Folk Melodies in the Rite of Spring. Journal of the American Musicological Society, 3(33): 501-543.

Salmenhaara, E. 1990. Pyorteita vanavedessa. Uuno Klami 90 vuotta. Helsinki: Uuno Klami Society.

\begin{abstract}
„The Russian Modernists such as Prokofiev and Stravinsky and new Spanish music shook me up from top to toe. ... It was around that time that I went to the Sorbonne to borrow a copy of the Kalevala" (Virtanen 1945: 613-614). Abovementioned sentence was said by the Finnish composer Uuno Klami (1900-1961), who during his studies in Paris (19241925) was fascinated by the music of Igor Stravinsky, Maurice Ravel, Sergei Prokofiev and Manuel de Falla. Inspiring by achievements of Western modernists Klami wanted to break up the tendency begun by Jean Sibelius to treat Finnish epos Kalevala only in the national romantic spirit. In 1930s Klami under the impression of The Rite of Spring's score started composing vocal-instrumental work based on topics from Kalevala. However during working on it he changed his preliminary plans and composed a five-movement symphonic suite Kalevala-sarja op. 23 [Kalevala Suite]: Maan synty [The Creation of the Earth], Kevään oras [The Sprout of Spring], Terhenniemi, Kehtolaulu Lemminkäiselle [Cradle Song for Lemminkäinen], Sammon taonta [The Forging of the Sampo].
\end{abstract}


Kalevala-sarja started in Klami's output searching for his personal voice and influenced on his further style. Nowadays the score is regarded as the most significant Finnish orchestral compositions from the first half of the $20^{\text {th }}$ century, and very often is called The Finnish Rite of Spring. The article's goals are: to introduce into Klami's output, to demonstrate the genesis and inspirations of the suite Kalevala-sarja and to briefly analyse particular movements of the composition in the light of European modernistic influences.

Keywords: Uuno Klami; Kalevala; Igor Stravinsky; Maurice Ravel; twentieth century Finnish music. 